\title{
As esculturas cokwe como respostas às assimetrias civilizacionais
}

Juliana Ribeiro da Silva Bevilacqua ${ }^{1}$

RESUMO: Fundada em 1917, a Companhia de Diamantes de Angola (Diamang) ocupava uma vasta região da Lunda Norte e Lunda Sul. Além das ações voltadas para a exploração de diamantes, essa empresa concessionária constituiu em 1936 o Museu do Dundo, um espaço destinado a colecionar objetos relacionados, sobretudo, aos povos que habitavam a sua área de atuação. Os objetivos cada vez mais ambiciosos e o receio da extinção de uma arte reminiscente do "tempo tribal" levaram o Museu do Dundo a organizar não apenas expedições de recolhas de objetos, mas também a contratar e manter "protegidos" em seus domínios escultores de madeira e de marfim a fim de evitar que as transformações ocasionadas pela situação colonial influenciassem os trabalhos desses homens. Este artigo tem como objetivo apresentar algumas reflexões sobre como os anseios fictícios do Museu em relação a esses escultores foram fundamentais para compreender as constantes tensões e dificuldades em enquadrar em seu espaço não apenas esses próprios homens, mas também as suas produções.

PALAVRAS-CHAVE: Colonialismo. Companhia de Diamantes de Angola. Museu do Dundo. Cokwe. Escultura.

ABSTRACT: The Companhia de Diamantes de Angola (Diamang) was founded in 1917 and occupied a vast region of Lunda's north and south areas. Aside from the activities around diamond mining this concessionary company also created a museum in 1936. The Museu do Dundo (Dundo Museum) was a space dedicated to collect objects related to the inhabitants who lived in the area exploited by the company. The increasingly ambitious objectives of the Museum and the concern regarding the disappearance of a reminiscent art from "tribal times" resulted not only in the organization of collecting expeditions but also in the recruitment and "protection" of wood and ivory sculptors inside the company's domains to avoid that their work were influenced by changes caused by the colonialism. The main objective of this paper is to present some considerations regarding how the museum's fictitious expectations regarding these sculptors were crucial to understand the continuous tensions and difficulties faced to accommodate not only these men but also their work in its space.

\author{
1. Historiadora, mestra e \\ doutora em História Social \\ pela Universidade de São \\ Paulo. E-mail: <jurisil@ \\ gmail.com>.
}


3. Na bibliografia não há um consenso sobre como se referir a esse povo. Mais recentemente, tanto em Angola quanto na historiografia, tem se intensificado o uso do termo cokwe. Nas produções bibliográficas do período colonial há uma recorrência do termo quioco, ou kioko, além de outras formas apresentadas por José Redinha, tais como: "Bachoko e Badjoko (formas particularmente belgas); Bajok, Bakioko, A'hioko, Chiboque (Capelo e Ivens); Tutshiokwe, Utchokwe, Khioko, Kioke, Kiokjo, Makioko, Ma-Quioco, Maquibocue [...]". Redinha (1971, p.21). Neste artigo optou-se por utilizar o termo cokwe.

4. O uso do termo indígena neste artigo está relacionado ao Estatuto do Indigenato. Instituído em 1926, esse estatuto foi um conjunto de dispositivos legais que levava às últimas consequências a noção da "diferença do estado civilizatório" das populações indígenas das colônias continentais africanas e os cidadãos da metrópole e habitantes de Cabo Verde, Índia e Macau. Dessa forma, o acesso à cidadania portuguesa era negado àqueles que não conseguiam comprovar requisitos como autonomia financeira, costumes europeus e conhecimento da língua portuguesa. Em 1946, o estatuto passou a vigorar também para as colônias de São Tomé e Príncipe e Timor. Thomaz (2001, p.60-61).

5. De acordo com Marie-Louise Bastin, a máscara Catoio ou Katoyo é uma máscara de dança que representa o europeu: cimba$l i$. Tem como características a testa proeminente e o nariz afilado. $\mathrm{O}$ mascarado exibe um pênis atado à vestimenta expondo-o furtivamente ao dançar para fazer
KEYWORDS: Colonialism. Companhia de Diamantes de Angola. Dundo Museum. Cokwe. Sculpture.

\section{A Diamang e o Museu do Dundo}

A Companhia de Diamantes de Angola (Diamang) foi fundada em 1917 e ocupava uma vasta região que abrangia a Lunda Norte e a Lunda Sul. Foi sob o discurso da apreciação, salvação e preservação das artes indígenas que essa empresa concessionária criou, em 1936, o Museu Gentílico, nome alterado, posteriormente, para Museu do Dundo. Localizado na sua sede administrativa (Dundo), era "destinado a recolher e colecionar todos os objetos característicos usados pelas raças indígenas da região, especialmente lundas e quiocos". Essa iniciativa, conforme consta em documento, "impunha-se pela necessidade de evitar que se perdessem, por ação do tempo e contato com os nossos usos e costumes, os principais vestígios da vida gentílica tradicional". ${ }^{2}$

A partir dessa premissa, o Museu do Dundo colocou em prática um projeto de "salvação" da arte indígena por meio da organização de campanhas e expedições de recolhas de objetos considerados etnográficos, pertencentes, sobretudo, às populações da região da Lunda, área de predomínio cokwe ${ }^{3}$ e lunda e o lugar onde a Companhia estava instalada.

O aumento surpreendente do acervo do Museu do Dundo ano a ano reflete o sucesso das campanhas de recolhas que eram, em geral, bem-sucedidas porque tinham uma estrutura organizacional bastante sofisticada, apesar dos poucos recursos materiais, inclusive provimentos, destinados à comitiva. Sofisticada, porque era pensada de forma a atrair as populações a serem visitadas, não apenas recompensando-as com benefícios materiais, mas obedecendo aos códigos simbólicos compartilhados por essas comunidades. Assim, as expedições contavam com auxiliares indígenas, suas mulheres - que em geral preparavam os alimentos - e até um escultor. Além dessas pessoas, as campanhas, não raro, contavam com a figura de um soba (chefe tradicional) ou sobeta - como os colonizadores chamavam os chefes tradicionais - que, além de atuar como guia, fazia a intermediação com os chefes dos sobados visitados, cumprindo as "praxes indígenas". ${ }^{4}$

Os trabalhadores deslocados para cumprir regime de contrato na Diamang também foram fundamentais na formação do acervo do Museu do Dundo. Dentre os milhares de homens que passavam pela sede administrativa da Companhia para serem alocados nas minas, havia aqueles que em suas aldeias desempenhavam o papel de sacerdotes e de bailarinos mascarados, entre outros, e que detinham objetos desejados pelo Museu. Um exemplo é o de um bailarino natural do Cacolo que em 1953 cedeu o seu traje e a respectiva máscara ao Museu. Tratava-se de uma máscara Catoio, rara por ter sido feita em madeira e não em resina, tipo mais comum. ${ }^{5}$ 
Não era menor a importância do cinto de dança desse mesmo bailarino, também adquirido e avaliado por funcionários do Museu como um dos melhores da coleção. Era formado por duas campainhas, quatro guizos, vários chocalhos, e pesava mais de 6 quilos. Cito: "Deste cinto retirou o bailarino alguns amuletos que religiosamente guardou, para colocar noutro cinto que tenciona fazer. A bem trabalhada machadinha com que habitualmente dança, também foi adquirida".6

caso desse bailarino que cedeu objetos não foi uma exceção. Durante o ano de 1952 o Museu conseguiu adquirir por volta de 35 peças, quase todas trazidas de longe pelos trabalhadores contratados para o serviço na Diamang. Em 1957, já havia aumentado para 120 o número de objetos adquiridos de contratados das regiões de Mona Quimbundo, Xá Cassau, Alto Chicapa, Minungo, Capenda e Saurimo, em trânsito no Dundo.' Esse número aumentou ao longo dos anos. Em 1963, por exemplo, foram adquiridos de trabalhadores pelo menos 500 objetos "de boa qualidade". $\bigcirc$ documento do referido ano ainda deixa claro que só não foram adquiridos mais porque o carro do Museu que faria o transporte estava na oficina para conserto. $\bigcirc$ que a documentação não deixa claro é como esses trabalhadores de regiões distantes chegavam ao Dundo com esses objetos. É bastante provável que no momento do recrutamento esses homens fossem orientados a levar as peças que podiam interessar ao Museu. $\bigcirc$ processo de recrutamento, muitíssimo tenso e marcado muitas vezes pela violência física e simbólica, não devia dar muita escolha para que esses trabalhadores decidissem não colaborar.

interesse do Museu do Dundo não se limitava aos objetos ditos etnográficos. O Museu tinha como ambição documentar todos os aspectos da vida indígena, o que incluía levar para dentro desse espaço o passado histórico dessas populações por meio do aparato material de seus ancestrais, além da busca por objetos arqueológicos ou aqueles encontrados em iculos, ou seja, em antigas aldeias abandonadas. Ademais, havia o grande interesse em documentar o meio ambiente que cercava essas populações, por meio da coleta de exemplares da fauna e o registro da flora da região da Lunda. É claro que não podiam ficar de fora do registro da história dessas populações documentadas pelo Museu do Dundo a dominação e a presença portuguesas, representadas nesse espaço por documentos e objetos que reverenciavam as campanhas de ocupação e pacificação de Angola e, de forma específica, da região da Lunda, além da própria história da instalação da Companhia de Diamantes de Angola.

Todos os objetos adquiridos eram avaliados pelos funcionários portugueses do Museu e se considerados "merecedores" ocupavam uma das salas desse espaço controlado pela Diamang, mas que era dedicado "aos povos da Lunda e à sua história", conforme indicação na Sala de Honra do Museu (Figura 1). a plateia rir. Manuel Jordán complementa que a máscara Catoio faz parte de um conjunto de máscaras que "são representadas para dramatizar os comportamentos selvagens ou indomáveis, absurdos e loucos". Bastin (2009, p.288), Jordán (2000, p.95).

6. Diamang (1953b, p.1, 2).

7. Diamang (1957b, p.15, 16). 


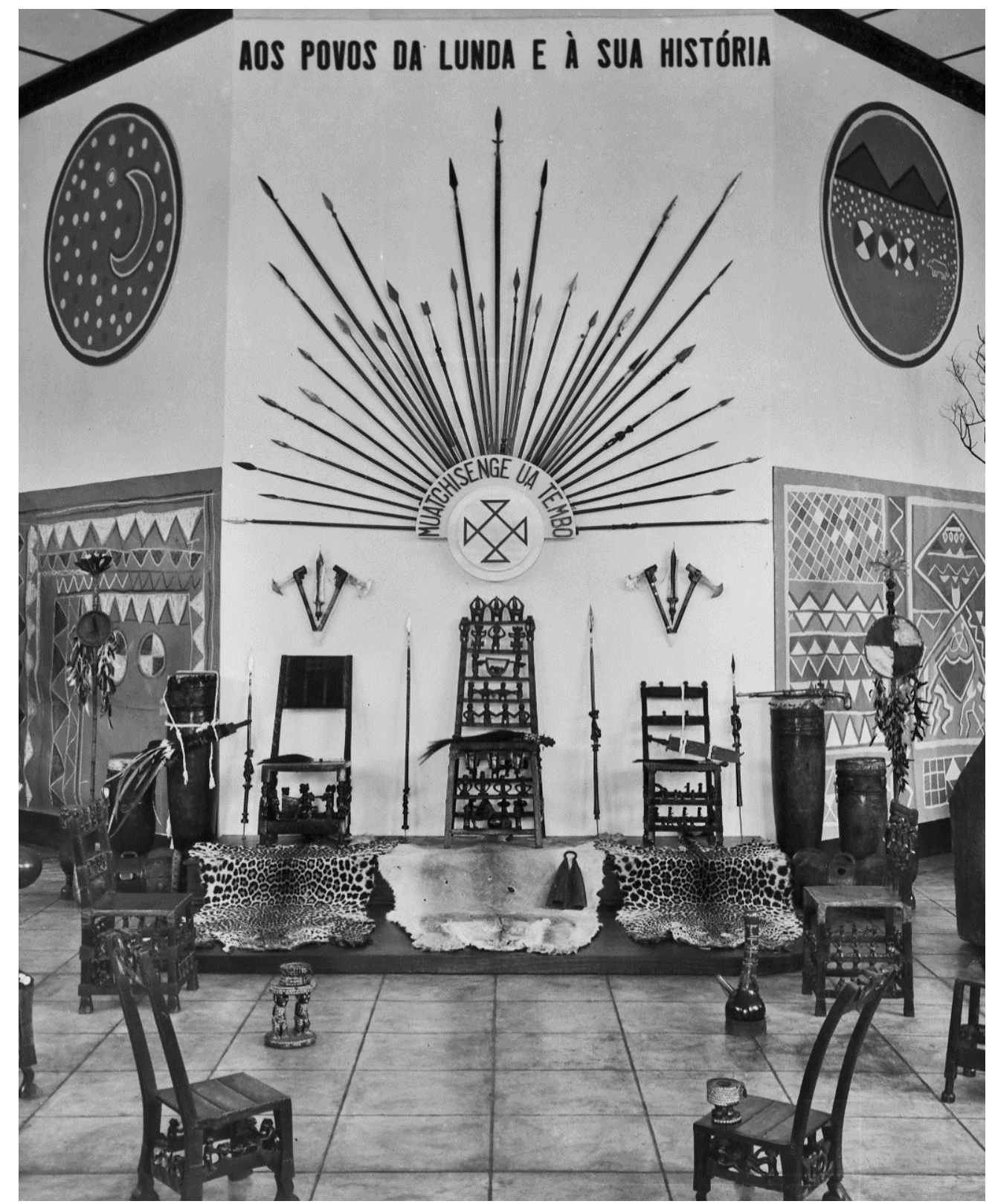

Figura 1 - Detalhe da Sala de Honra onde é possível ver a dedicatória "Aos povos da Lunda e à sua História". Fonte: Diamang (1950, p.26).

\section{Os escultores do Museu do Dundo}

Além de um projeto de "salvação" envolvendo a preservação dos objetos que circulavam entre as populações locais, o Museu do Dundo, por meio do seu conservador José Redinha, deu início conjuntamente a um projeto de "proteção" aos artistas indígenas para evitar que esses especialistas desaparecessem 
em decorrência das mudanças provocadas pela situação colonial. ${ }^{8}$ Em 1942, José Redinha já havia chamado a atenção num relatório sobre o intenso processo de desaparecimento dos artistas indígenas. De acordo com o documento:

Com a morte de Camba Cafaca, desapareceu mais um escultor gentílico. (...) Pouco a pouco, estes artistas indígenas vão desaparecendo. Uns, morrem, outros, como Camba Luango, desaparecem. O primeiro foi para o Congo, o segundo para a Rodésia. Estes dois mestres eram os mais notáveis escultores que nós conhecíamos na Lunda. Os seus trabalhos eram cheios de sinceridade e caráter rácico. Convidados pelas autoridades locais a fazer trabathos de forma contrária ao que sua rotina e índole permitiam, acabaram por fugir. (...) Muitos outros artistas, por encomendas do comércio ou de criaturas com péssimo gosto, deturpam a sua arte natural fazendo cópias de artefatos europeus. Outros vão abandonando a sua arte e morrem sem deixar escola. Achamos que seria da maior conveniência a promulgação de qualquer diploma tendente a proteger a arte indígena, e devemos acrescentar que, se não se tomarem sérias providências neste sentido, acabar-se-á o que resta da arte gentílica, já de si bastante decadente. ${ }^{9}$

Foi o receio do desaparecimento de uma arte "já bastante decadente", nas palavras do conservador, que levou o Museu do Dundo, após a segunda metade da década de 1940, a manter sob o seu domínio um grupo de escultores indígenas que ao longo do tempo variou entre três e oito homens. ${ }^{10}$ A preocupação em reter os escultores existentes na região da Lunda se manteve ao longo dos anos e, em 1947, ainda era evidente o esforço que o Museu fazia para encontrar esses profissionais. Segundo consta em um dos relatórios desse ano:

Tem-se desenvolvido alguma atividade no sentido de encontrar mestres indígenas escultores, mas os resultados têm sido de pouca recompensa. A influência da colonização aumenta dia a dia. Assim, as artes indígenas tendem a desaparecer, fenômeno este que, aliás, se verifica por toda a parte. Alguns escultores e mestres de outras artes persistem ainda em trabalhos de caráter artístico devido à proximidade do Museu e à propaganda desenvolvida. Não virá longe o dia em que os nossos relatórios mensais só esporadicamente assinalem a aquisição de um ou outro objeto digno de nota. ${ }^{11}$

Em 1953, apesar dos esforços, o Museu do Dundo tinha conhecimento que as suas ações de preservação não seriam facilmente recompensadas. $\bigcirc$ seu relatório anual, quase dez anos após o início das contratações dos escultores, evidencia que:

Os artistas indígenas não têm senão um relativo interesse pela sua arte. Ser alfaiate, pedreiro, ou motorista, apresenta-se para eles, coisa muito mais distinta do que serem artistas. Reconstituir o ambiente tribal antigo, onde, realmente, os artistas tinham uma alta cotação e prestígio, inclusive político, não é possível, por não ser fácil manter-se por seu pé. $\bigcirc$ único processo viável, para o meio e circunstâncias locais, será acompanhá-los de perto, conduzi-los de modo a não os alterar e desorientar, e fazê-los conseguir bons resultados econômicos, que os compense da execução duma arte de onde não retiram brilho que os anime. Nas zonas de colonização, falar de artistas indígenas apaixonados pela sua arte é pura literatura. Não existem. Também é difícil ressuscitá-los e muito mais criá-los. Pode-se, realmente, é retardar bastante o seu desaparecimento, e tem sido esse o objetivo do Museu do Dundo. Pode mes-
8. Apesar da peculiaridade do caso dos escultores do Museu do Dundo, esse tema foi pouco explorado pelos pesquisadores. Destacam-se os seguintes trabalhos: Porto (2009), Amaral; Martins (2010, p. 157-174).

9. Diamang (1942, p.11).

10. O Museu também manteve em seu quadro de funcionários outros profissionais, como esteireiros e tecelões. Em 1945 trabalhava no Museu "o filho do soba Sauache do Sombo, que é um dos raros mestres tecelões que ainda se encontram”. Diamang (1945).

11. Diamang (1947, p.1) 
12. Diamang (1953a, p.19).

13. Diamang (1953a, p.19).

14. A Aldeia Museu ocupava uma área anexa ao Museu do Dundo. Tratava-se de uma reprodução de uma típica aldeia cokwe da época. Ao longo dos anos, essa aldeia passou por várias transformações, inclusive de caráter arquitetônico. mo afirmar-se que se não fosse essa influência, não se contava, nos arredores, por muitos quilômetros, um único artista indígena. ${ }^{12}$

Para evitar o aumento da influência da colonização sobre esses escultores e uma possível "contaminação" com uma produção que não thes era própria, algumas decisões foram tomadas pelo Museu. Além da necessidade de uma oficina de trabalho, outras medidas sugeriam:" afastar os escultores, nas horas de trabalho, das suas povoações, onde o ambiente, modificado pela colonização, Thes é desfavorável";"interessá-los profissionalmente na sua arte"; "levá-los ao aperfeiçoamento dos seus padrões". ${ }^{13}$ Aliás, o Museu do Dundo, símbolo do colonialismo português na África, ainda que fosse um espaço construído por uma iniciativa privada, parecia realmente ser visto por seus funcionários como um reduto livre da ação do colonialismo. A grande contradição reside no fato de que quem teria o papel de manter os escultores protegidos das influências advindas da situação colonial seriam os próprios colonizadores. Por isso, os padrões estéticos a serem aperfeiçoados eram de modo geral definidos não pelos escultores, mas por funcionários portugueses do Museu e, sobretudo, por membros da direção da Companhia de Diamantes de Angola.

Um ambiente de trabalho evocativo foi considerado de grande importância, por isso os escultores trabalhavam na Aldeia Museu, ${ }^{14}$ onde outros especialistas como ferreiros, esteireiros e dançarinos trabalhavam e/ou moravam com suas famílias. Assim, se as aldeias reais estavam ameaçadas pelas contaminações da situação colonial, a aldeia projetada pelo Museu do Dundo estava protegida, porque quem controlava o contato com os "elementos externos" era o próprio Museu. (Figura 2)

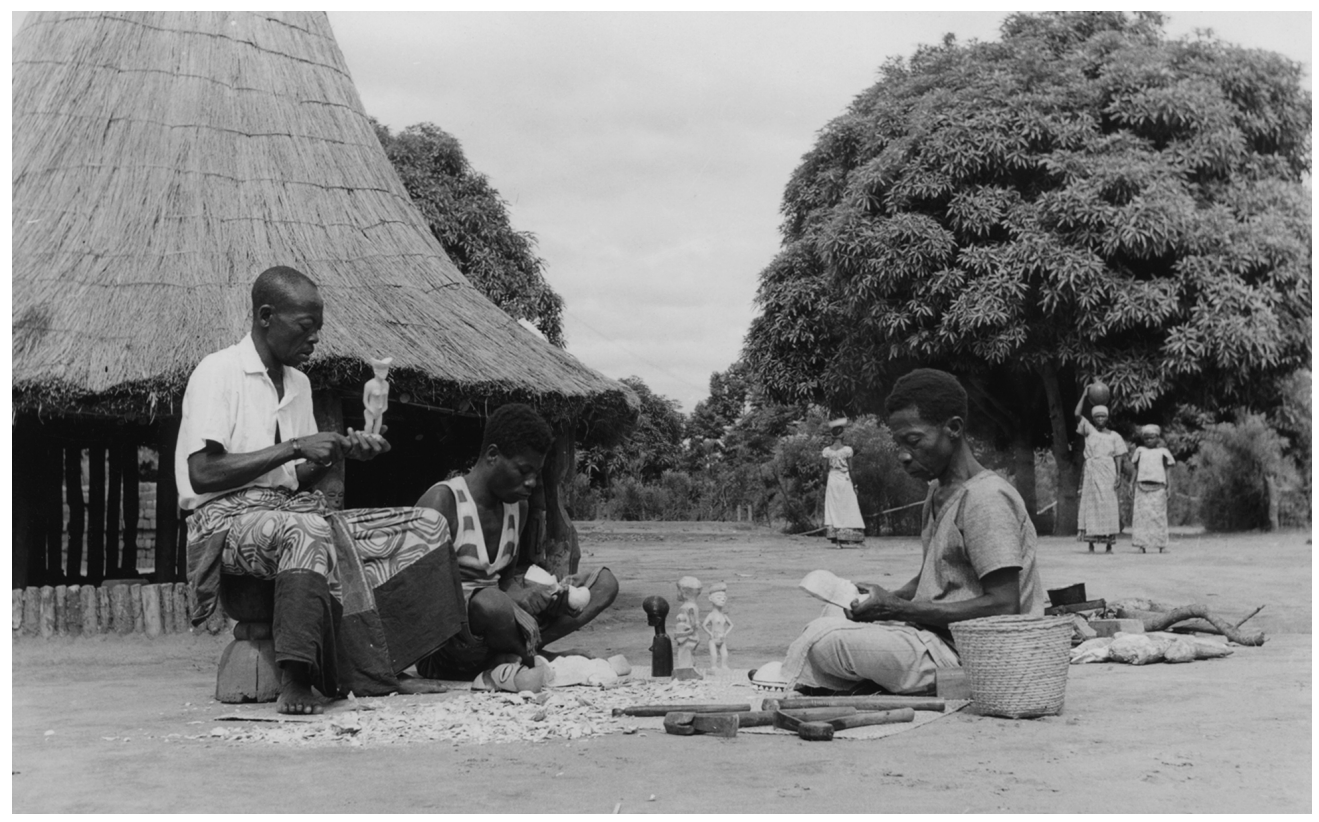

Figura 2 - Escultores trabalhando na Aldeia Museu. 1954. Arquivo da Diamang. Acervo do MAUC. 
No ano de 1953, o Museu do Dundo contava com quatro escultores. No ano seguinte eram três trabalhando regularmente. Já em 1955 o Museu contava com seis escultores. $\bigcirc$ ritmo de trabalho desses homens era, com frequência, intenso. Como de costume, as peças restantes eram enviadas para a sede da Companhia em Lisboa, assim como utilizadas para presentear visitantes ilustres, enquanto outras eram adquiridas por empregados da Diamang. Em 1957 trabalhavam na Aldeia do Museu do Dundo, além de um tecelão chamado Caluimbe e um esteireiro de nome Muacanhica, os seguintes escultores: Mulumba Canhanga (marfim); Chamua Cariango (madeira); Muachonge (madeira); Muanguelengue (madeira); Carinhique (madeira); Comboia (madeira); e Sá Chumba (madeira)..$^{15}$

Por sua vez, no ano de 1959, o Museu contava com um escultor de madeira a menos. A produção, no entanto, não foi pequena, ainda mais se forem contabilizadas, além dos 108 objetos, conforme tabela a seguir, 130 colunas que os escultores produziram para a varanda das habitações e para a txota da Aldeia Museu; 14 "postes-ídolos e algumas montagens que constituem o cenário para a apresentação de danças exibidas pelos grupos folclóricos". Esculpiram também 8 colunas ou "postes totêmicos destinados ao terreiro de festas" 16 (Tabela 1).
15. Na documentação consultada os nomes dos escultores não apresentam um padrão no que diz respeito a sua grafia.

16. Diamang (1959, p.5).

Tabela 1: Produção dos escultores do Museu do Dundo no ano de 1959

\begin{tabular}{|c|c|c|}
\hline \multirow{2}{*}{ ESCULTORES } & MATERIAL & PEÇAS PRODUZIDAS \\
\hline Mulumba Canhanga & Marfim & 15 trabalhos diversos \\
\hline Caliango (ou Cariango) & Madeira & 7 estatuetas e 16 máscaras \\
\hline Muanguelengue & Madeira & 9 estatuetas e 11 máscaras \\
\hline Carinhique & Madeira & 6 estatuetas e 16 máscaras \\
\hline Muachonge & Madeira & 5 estatuetas e 15 máscaras \\
\hline Sa Chamua (dispensado em setembro) & Madeira & 4 estatuetas e 4 máscaras \\
\hline & & 108 OBJETOS \\
\hline
\end{tabular}

* Fonte: Diamang (1959, p. 5)

Os escultores do Museu do Dundo eram rigorosamente vigiados e orientados sobre como deveriam desenvolver seus trabalhos e todas as esculturas produzidas passavam por uma avaliação e aprovação de alguns funcionários portugueses do Museu, em particular, de membros do alto escalão da Companhia de Diamantes de Angola, como é o caso do administrador delegado Ernesto de 
17. Ernesto de Vilhena (4/6/1876 - 15/2/1967) foi comandante em Moçambique (1889-1901) e em 1911 atuou como governador do Distrito de Lourenço Marques. Nesse mesmo ano foi também diretor da Sociedade de Geografia de Lisboa. Em 1917 assumiu a Pasta das Colônias. De 1919 até a sua morte, em 1967, desempenhou as funções de administrador-delegado da Companhia de Diamantes de Angola.

Diamang (1956, p.19).

18. Diamang (1958a, p.7).

19. Diamang (1957a, p.49).

20. Amaral; Martins (2010, p.164).

21. Além de ter exercido importante cargo na Administração da Diamang em Lisboa, Ernesto de Vilhena foi o grande idealizador do Museu do Dundo. Considerado um homem muito culto, era um grande colecionador de arte e dono de uma importante biblioteca com exemplares raros. Apesar de ter vivido em Portugal, praticamente todas as decisões em relação ao Museu do Dundo eram tomadas por ele ou passavam por sua aprovação.
Vilhena. ${ }^{17}$ As esculturas que eram avaliadas como inferiores, em geral aquelas consideradas fora do padrão tradicional cokwe, eram descartadas e algumas vezes queimadas. Em janeiro de 1958, por exemplo, 14 trabalhos dos escultores foram destruídos "por serem nitidamente inferiores". 18 Um documento do ano de 1957 nos oferece uma ideia de quais eram os critérios para aceitar ou recusar uma peça:

[...] uma percentagem de cerca de um terço rejeitada por deficiência de execução, má qualidade do pedaço de madeira empregado, e por motivo de manchas adquiridas na operação de enegrecerem, como usam, as esculturas. Com este terço de peças defeituosas ou inferiores se constituiu o que designamos refugos, sendo destruídas as peças de todo inaproveitáveis, e guardadas as restantes de onde se retiram as que se oferecem a colaboradores do Museu. As peças perfeitas entram na coleção dos escultores modernos, independente das coleções do Museu. ${ }^{19}$

Como bem mostraram Maria do Rosário Martins e Ana Rita Amaral, a produção dos escultores do Museu do Dundo, em geral, oscilava entre dois fins: a formação de um lote onde eram reunidas as melhores peças de cada escultor e a manufatura de peças utilizadas para presentear visitantes ilustres do Dundo ou para serem enviadas para a sede em Lisboa e para Luanda com esse mesmo fim. ${ }^{20}$

As peças produzidas que não interessavam ao Museu eram vendidas a funcionários interessados, mas essas vendas foram suspensas em meados de 1950. Essa medida, no entanto, acabou causando transtornos ao Museu que estava com seu depósito repleto de peças tidas como refugo. Um dos motivos relacionados à suspensão de venda de peças consideradas pelo Museu do Dundo como refugo está ligado à necessidade de controlar a qualidade das peças que circulavam, uma vez que os escultores estavam vinculados ao Museu. A ideia disseminada por esse espaço era a de preservar as chamadas "artes indígenas" e a circulação de peças consideradas inferiores poderia denunciar o fracasso dessa iniciativa.

Com o passar dos anos, o controle sobre a produção desses escultores foi se intensificando. No ano de 1957 o Museu do Dundo determinou que fosse feito um carimbo de ferro para marcar a fogo a palavra "cópia" nas peças executadas, diferenciando as peças produzidas pelos escultores do Museu das peças consideradas "originais" e "antigas" do seu acervo (Figura 3).

As frequentes mudanças de orientação sobre o que fazer com as peças dos escultores do Museu do Dundo revelam que essas produções estavam num limiar entre a arte considerada "para turista" e a arte recolhida na Lunda. Ao longo dos anos algumas peças entraram no acervo, porém mais tarde foram retiradas. Outras entraram não como peça da coleção, mas como objetos decorativos das salas. Em 1957 era colocada em prática uma determinação de Ernesto de Vilhena de manter as peças dos escultores do Museu do Dundo independentes das coleções do Museu. ${ }^{21}$ Essa coleção deveria ser organizada à parte, onde:

[...] podem e devem formar uma galeria de particular interesse etnográfico, por representarem um testemunho cultural dos últimos escultores de matriarcado, sejam os derradeiros da região, mantidos a expensas da Diamang, pois, caso contrário, teriam desde há muito adotado as 
profissões de alfaiates, pedreiros ou outras, em plena voga nas zonas circunvizinhas do Dundo, donde são originários. E quando se diz derradeiros escultores de matriarcado, se expressa uma realidade iminentemente objetiva, não só por serem os últimos nesta região, como também porque os seus congéneres das regiões em redor são escultores sim, mas não de matriarcado, no sentido cultural do termo, pois, entregues a si mesmos, ou, o que é muito pior, ao gosto de entidades que pretendem orientá-los, estes derradeiros artistas apenas executam uma arte falsificada no conceito, na inspiração e até na técnica, e que nada tem de comum com a escultura matriarcal dos caçadores-escultores do Nordeste angolano. ${ }^{22}$

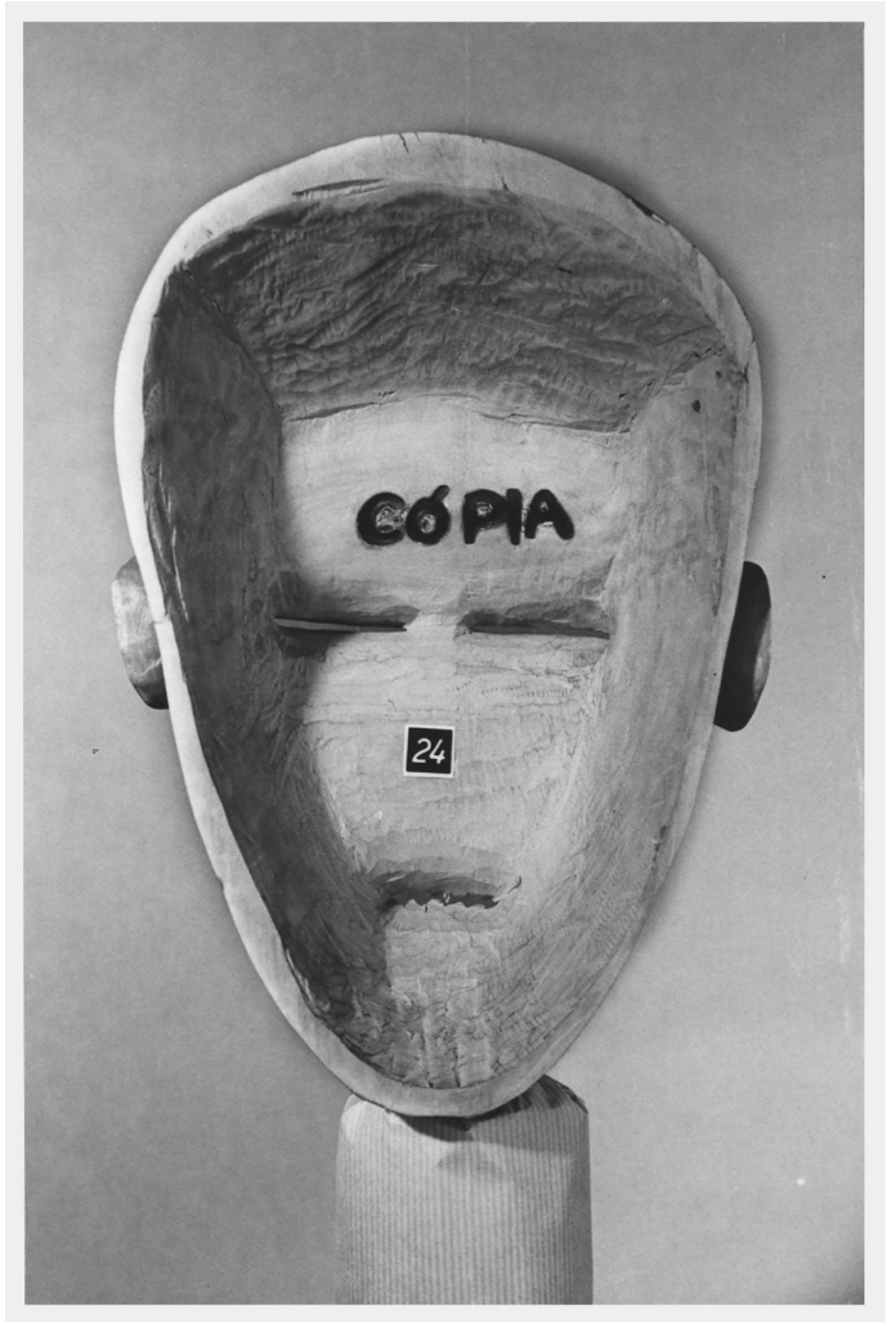

22. Diamang (1957c, p. 1920).

23. Porto (2009, p.454).

Figura 3 - Verso de uma máscara onde se visualiza a palavra "Cópia". Fonte: Diamang (1957a).

Apesar de serem considerados "os últimos escultores de matriarcado" e - Museu estivesse desempenhando um papel de resgatar essas figuras em vias de extinção, suas produções não eram consideradas autênticas. De acordo com Nuno Porto, "é a acuidade dos processos de trabalho tradicionais que confere autenticidade ao modo de produção destes objetos. $\bigcirc$ estatuto de cópia destes artefatos é, portanto, atenuado pelo fato de resultarem de um processo de produção autêntico". ${ }^{23} \mathrm{O}$ u seja, o resultado de um processo de produção, por mais que fosse 
24. Errington (1998, p. 72).

25. Para uma discussão acerca de autenticidade, ver, em especial, o capítulo "The quest for authenticity and the invention of African art”, em Steiner (1994).

26. Os kuba ocupam parte da atual República Democrática do Congo e ficaram conhecidos pela sua sofisticada arte de corte.

27. Cornet (1975, p. 53).

28. Vansina (1972, p. 41-43).

29. Diamang (1958b, p. 12).

30. Kasfir (1999, p. 94).

31. Price (2000, p.87). considerado autêntico, resultaria, inevitavelmente, num objeto inautêntico. Isso porque o conceito mais disseminado de autenticidade em relação às produções artísticas africanas na época (e ainda hoje em muitos casos) determinava que as peças produzidas pelos escultores do Museu do Dundo seriam autênticas se, além de terem sido feitas por um artista do próprio povo (o que era o caso), elas fossem destinadas para as pessoas da própria cultura e para fins "tradicionais". ${ }^{24}$ Além desses fatores há muitos outros elementos que, quando reunidos, definem determinado objeto como autêntico, tais como mérito artístico, antiguidade e a intencionalidade do artista ao produzi-lo. ${ }^{25}$

As questões ligadas à cópia e à discussão sobre o valor dado às peças assim consideradas eram por certo mais uma preocupação do Ocidente do que das próprias culturas centro-africanas. Joseph Cornet enfatiza que ao menos dois reis kuba ${ }_{1}^{26}$ Kwete Mabintshi ma Mbek (1920-1939) e Mbope Mabintshi ma Mbek (1916-1929), tinham o hábito de orientar os escultores de sua corte a produzirem estatuetas ndop para serem oferecidas a visitantes europeus. ${ }^{27}$ Os ndop são estatuetas comemorativas representando diferentes reis (nyim) dos kuba. Elas têm como padrão uma figura humana com as pernas cruzadas num trono. As figuras usam emblemas pessoais como barretes na cabeça, cintos, além de espadas, todos os itens atribuídos à realeza kuba. Cada nyim é identificado por um símbolo pessoal do seu reinado (ibol) representado na escultura em frente à figura humana esculpida. ${ }^{28}$

Se em 1957 houve a determinação de que o carimbo com a palavra "cópia" fosse colocado nas peças dos escultores do Museu do Dundo, no ano seguinte outra medida foi tomada:

[...] para evitar a possibilidade de as peças de escultura dos escultores indígenas atuais poderem ser consideradas como datando do tempo tribal, as referidas peças, feitas pelos artistas privativos do Museu, devem levar, sem exceção, a marca, sigla ou assinatura do autor. ${ }^{29}$ (Tabela 2)

O que aparentava ser uma medida de valorização da autoria desses escultores tratava-se, na prática, de uma forma eficaz de controlar quantitativa e qualitativamente a produção desses homens. Mais do que isso: demarcar a autoria de uma peça africana significava por si taxá-la como inautêntica, "o anonimato do artista tem sido referido como condição indispensável à autenticidade, como uma nota de rodapé do conceito de um 'estilo tribal', a que o artista não consegue opor resistência, nem é capaz de mudar". ${ }^{30}$

Em "Anonimato e atemporalidade", capítulo do livro Arte primitiva em centros civilizados, Sally Price aponta que "na compreensão ocidental das coisas, uma obra originada fora das Grandes Tradições deve ter sido criada por uma personagem sem nome que representa a sua comunidade e cuja arte respeita os ditames de tradições antiquíssimas". ${ }^{31}$ Assim, as peças dos escultores do Museu do Dundo podiam até reproduzir os ditames de "tradições consideradas antiquíssimas", porém a presença da assinatura localiza essa produção no tempo e no espaço marcado por uma situação colonial e não mais num contexło cuja temporalidade 
é indefinida porque de tempos imemoriais, uma das características das obras consideradas autênticas.

Tabela 2: Tabela com os nomes dos escultores e suas respectivas siglas

\begin{tabular}{|c|c|}
\hline ESCULTORES & SIGLAS \\
\hline Cariango & \\
\hline Muanguelengue & \\
\hline Comboia & \\
\hline Carinhique & \\
\hline Muachonge & \\
\hline Mulumba & \\
\hline & \\
\hline
\end{tabular}

* Fonte: Reprodução minha baseada na informação contida em Diamang (1958b, p. 13).

De outra parte, são essas assinaturas que tornam possivel identificar a autoria desses escultores em diversas obras que hoje estão espalhadas pelo mundo. No acervo do Museu Antropológico da Universidade de Coimbra (MAUC) constam 194 peças assinadas, de acordo com Maria do Rosário Martins e Ana Rita Amaral. 
32. Agradeço a parceria e o empenho de Daliana Cascudo, que me permitiu identificar a autoria das máscaras do acervo do Instituto Câmara Cascudo.

33. Heusch (1988).
No acervo do Instituto Câmara Cascudo, na cidade de Natal, há três obras assinadas pelos escultores do Museu do Dundo. No ano de 1963, o folclorista brasileiro Câmara Cascudo visitou o Museu e foi presenteado com algumas máscaras. Recentemente, uma delas pôde ser identificada como do escultor Muachonje, enquanto as outras duas foram reconhecidas como do escultor Carinhique $^{32}$ (Figuras 4 e 5).
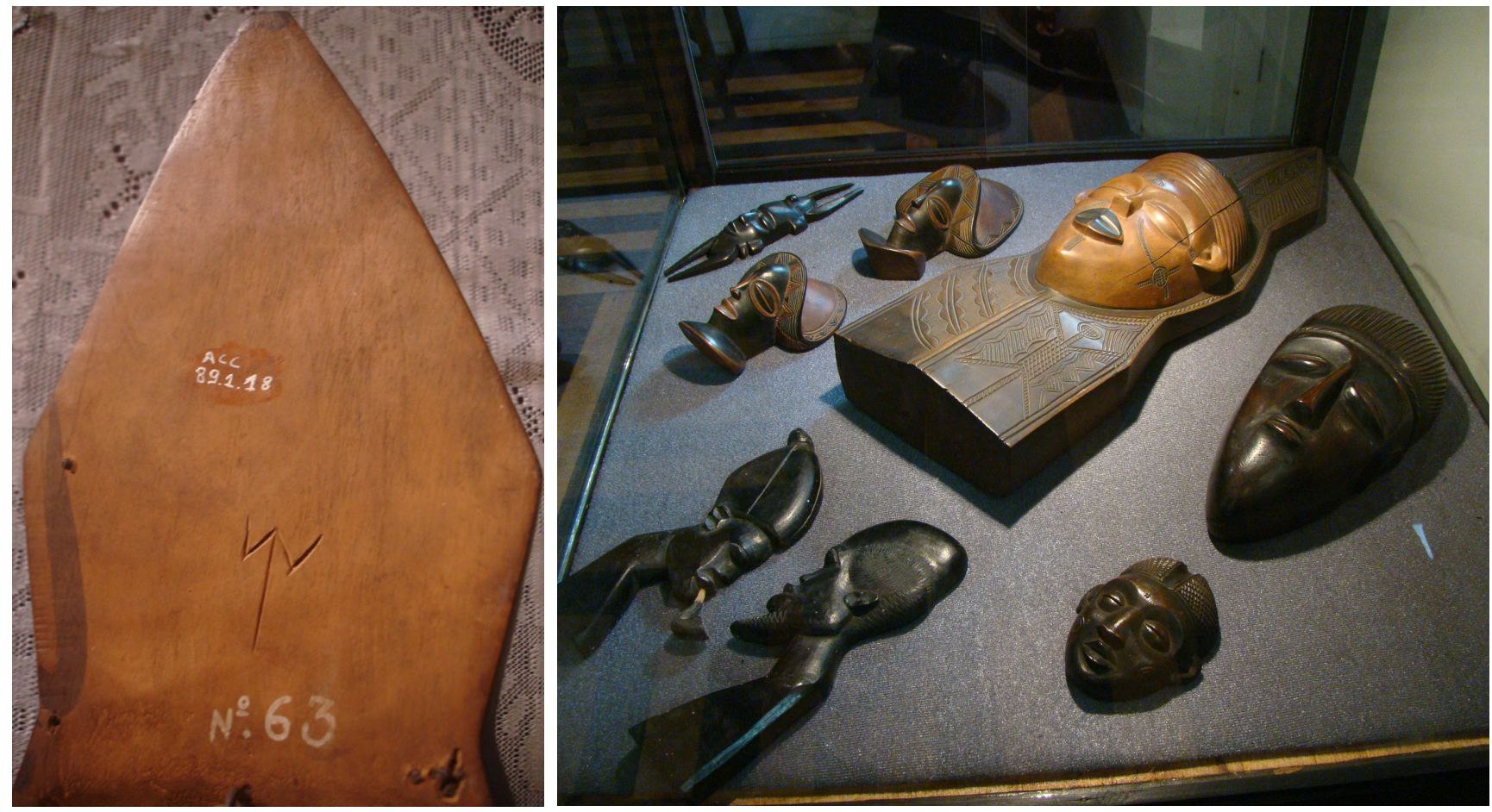

Figuras 4 (esq.) e 5 (dir.) - Foto à esquerda: verso de uma máscara produzida pelo escultor Muachonje, conforme tabela anterior. Na foto à direita é possível ver a mesma máscara no centro da vitrine. Acervo do Instituto Câmara Cascudo, Natal - RN. Foto de Daliana Cascudo, 2014.

Máscaras cokwe como mwana pwo e chihongo, as mais comuns entre esses povos, além de estatuetas reproduzindo cenas da vida indígena, bastões, mocas, apoios de nuca, lanças e cachimbos, eram alguns dos objetos esculpidos pelos artistas. A máscara chihongo é um equivalente masculino da pwo, que representa o ideal de beleza feminina. A chihongo, esculpida tanto em madeira quanto em resina, simboliza o poder e a riqueza e só podia ser usada pelo chefe de terra ou por um de seus filhos. De acordo com luc de Heusch, a pwo e a chihongo assumem funções distintas, mas de certa forma complementares: a fertilidade a que a primeira (pwo) remete depende, em última instância, da função mágico-religiosa do chefe de terra, encarnado pelo chihongo ${ }^{33}$ (Figura 6).

Reitero que a maioria das determinações sobre os temas e o modo como os artistas deviam produzir provinha de Lisboa, sede da Diamang, conforme fica evidente em carta de 1963 enviada ao Museu do Dundo por um dos diretores da 
Companhia, Júlio de Vilhena. ${ }^{34} \mathrm{Na}$ correspondência constam as seguintes orientações aos escultores:

Convém que não utilizem os fios de latão para simular argolas, juntas, em quantidade, pois essa forma de ornamento não pertence à tradição da Lunda, mas sim à de povos de outras regiões africanas (Sul de Angola, por exemplo). Haverá também, que chamar a atenção dos escultores para a necessidade de criação de outros tipos de figuras, para avaliarmos das suas capacidades de concepção. Assim, e também, por exemplo, novas posições ou atitudes, representação de diversas ocupações domésticas (além da já conhecida cena da mulher farinando mandioca). Insistir, ainda, por uma maior prática de figuras masculinas (sobas, caçadores, mensageiros, soldados, ferreiros e outros artistas). Nas cores, achamos boas as que mostram a última remessa: corpos em castanho, claro ou escuro, não encarniçado, reservando-se as colorações vermelhas para os acessórios e toucados. No mais, reconhecemos que os escultores estão trabalhando bem, e dando provas de bom gosto, tanto na modelação em geral, como nos pormenores relativos ao desenho das tatuagens e variedade de penteados. ${ }^{35}$

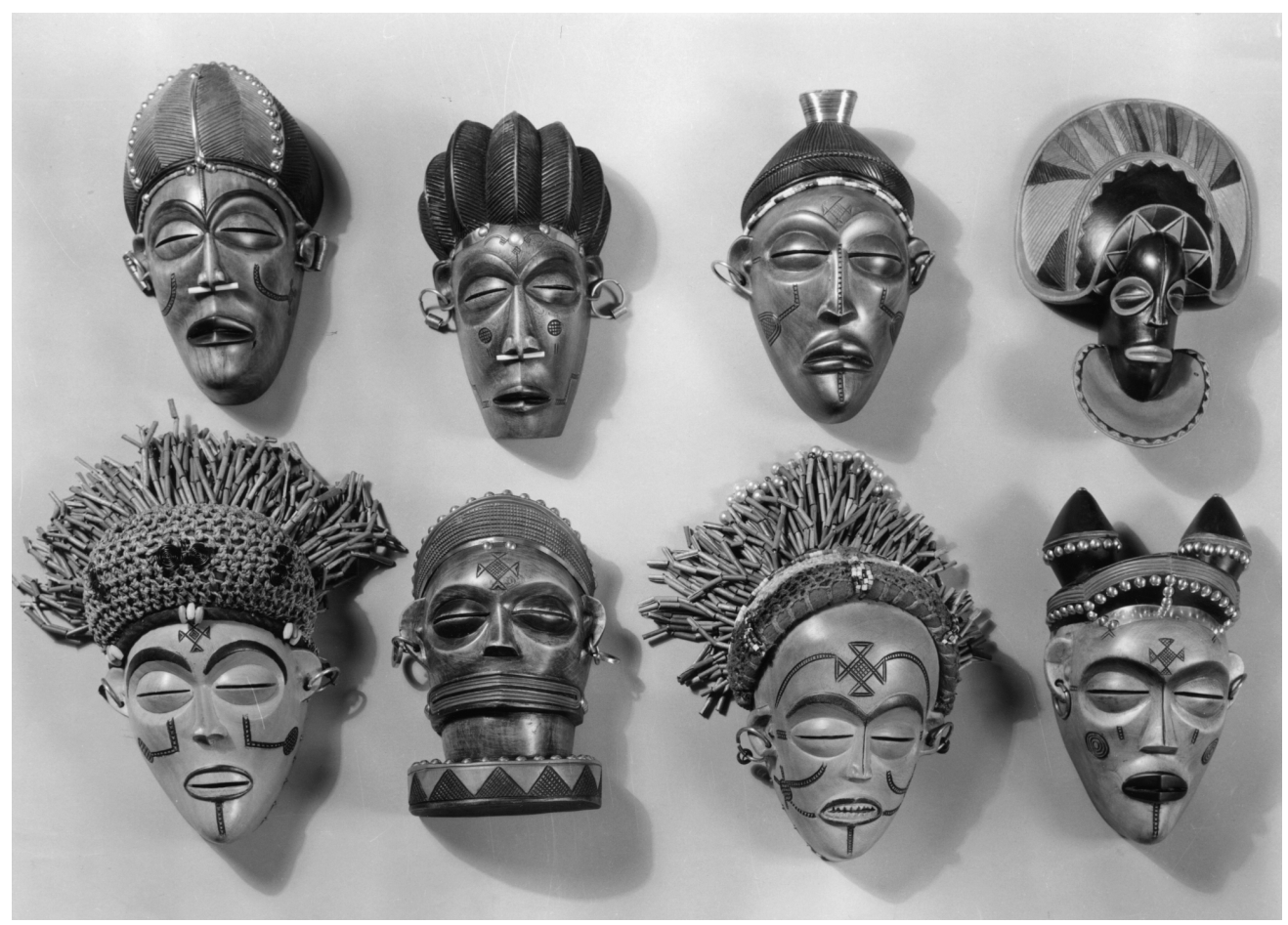

Figura 6 - Máscaras mwana pwo e chihongo la primeira do lado direito na parte superior da fotografia e a segunda máscara da esquerda para a direita na parte inferior da fotol produzidas pelos escultores do Museu do Dundo entre o segundo semestre de 1959 e janeiro de 1960. Arquivo da Diamang. Acervo do MAUC.

Como era geralmente a Metrópole que decidia quais objetos eram autênticos, era desse mesmo lugar que os diretores da Diamang determinavam o trabalho dos escultores do Museu do Dundo fixando, inclusive, o que era - ou não - típico dos povos da Lunda. Entretanto, mesmo diante do controle da produção desses homens, alguns escultores tentaram introduzir em suas esculturas novos
34. Júlio de Vilhena, filho único do comandante da Diamang Ernesto de Vilhena, além de ter desempenhado importante papel ao lado de seu pai na Administração da Companhia, foi figura-chave no desenvolvimento das ações dos Serviços Culturais da Diamang, que envolviam o Museu do Dundo.

35. Vilhena (1963). 
36. Fontinha; Videira (1966).

37. Diamang (1954, p.4) padrões ou elementos. Um exemplo é o do escultor Comboia, que em 1966 tentou criar um padrão de esculturas sem a face definida e ausência de marcas étnicas, tais como as escarificações consideradas típicas dos cokwe. Fotografias de um lote de peças foram enviadas para Lisboa, mas a proposta de Comboia parece não ter tido continuidade ${ }^{36}$ (Figuras 7, 8 e 9).

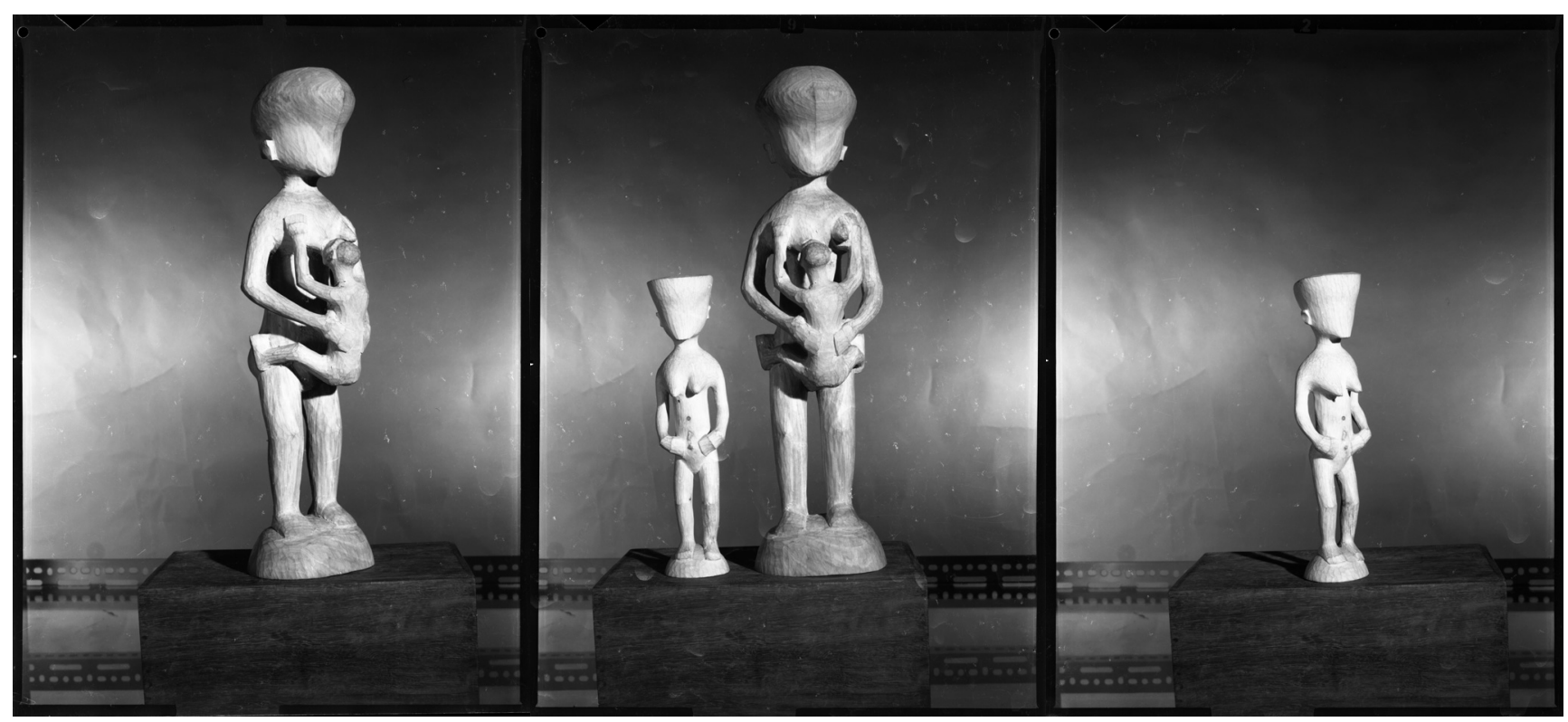

Figuras 7, 8 e 9 - Fotografias das peças feitas por Comboia e enviadas para a sede em Lisboa para avaliação. Fonte: Fontinha; Videira (1966).

A proposta feita por Comboia em passar a produzir peças sem detalhes específicos da cultura cokwe, tão prezados pelo Museu do Dundo, pode ser interpretada como uma maneira de amenizar o seu trabalho no cumprimento das pesadas metas de produção impostas pelo Museu, uma vez que a ausência de detalhes dinamizaria o fazer escultórico; como clara negação dos padrões escultóricos impostos pelo Museu; e, por fim, como um jeito de marcar que não queria mais reproduzir os padrões ligados a uma tradição cokwe por imposição dos portugueses, uma vez que deslocados do seu contexto original.

Era raro que as grandes inovações fossem bem-vindas, contudo, os escultores do Museu do Dundo tinham que percorrer as suas salas para terem contato com as obras consideradas do "tempo tribal" e, portanto, "originais" e "autênticas". Artistas de outras colônias na África, como do então Congo belga, também eram enviados ao Museu do Dundo para visitar as salas com o objetivo de "reavivar na sua arte o estilo tradicional", como foi o caso do escultor Swana Ndeke, descendente de cokwe da região do Tchicapa que em 1954 visitou o Museu do Dundo com esse propósito. Os funcionários não apenas o receberam como ofereceram alojamento e toda assistência necessária. ${ }^{37}$ 
Pelas razões referidas, as obras cokwe adquiridas na Metrópole portuguesa e expostas no Museu em sua sala denominada "África" serviam de modelo para os escultores treinarem e "reavivarem" as suas habilidades. Um exemplo é a escultura feita por Carinhique, baseada numa estatueta de Chibinda \|lunga, um caçador mítico ligado à fundação do Império Lunda, adquirida em Lisboa e enviada ao acervo do Museu do Dundo, em 1949. Logo que chegou ao Museu, a escultura foi considerada "uma das melhores e mais representativas peças de madeira da tribo kioka". Consta ainda que é muitíssimo parecida com uma escultura cokwe, de Angola, representada no livro de Leon Underwood e pertencente à coleção R.P. Bedford ${ }^{38}$ (Figuras 10 e 11 ).

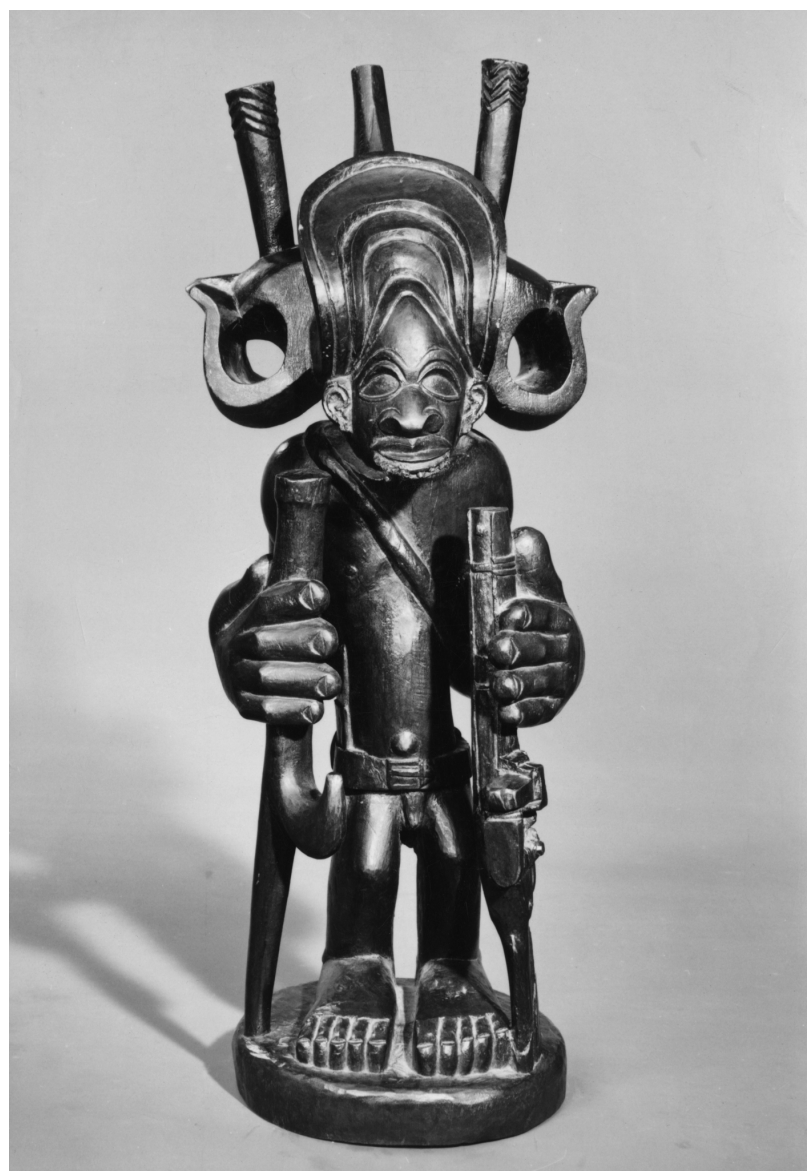

Figura 10 - Escultura representando o caçador mítico Chibinda llunga, adquirida em Lisboa e enviada para o Museu do Dundo. 1950. Arquivo da Diamang. Acervo do MAUC.

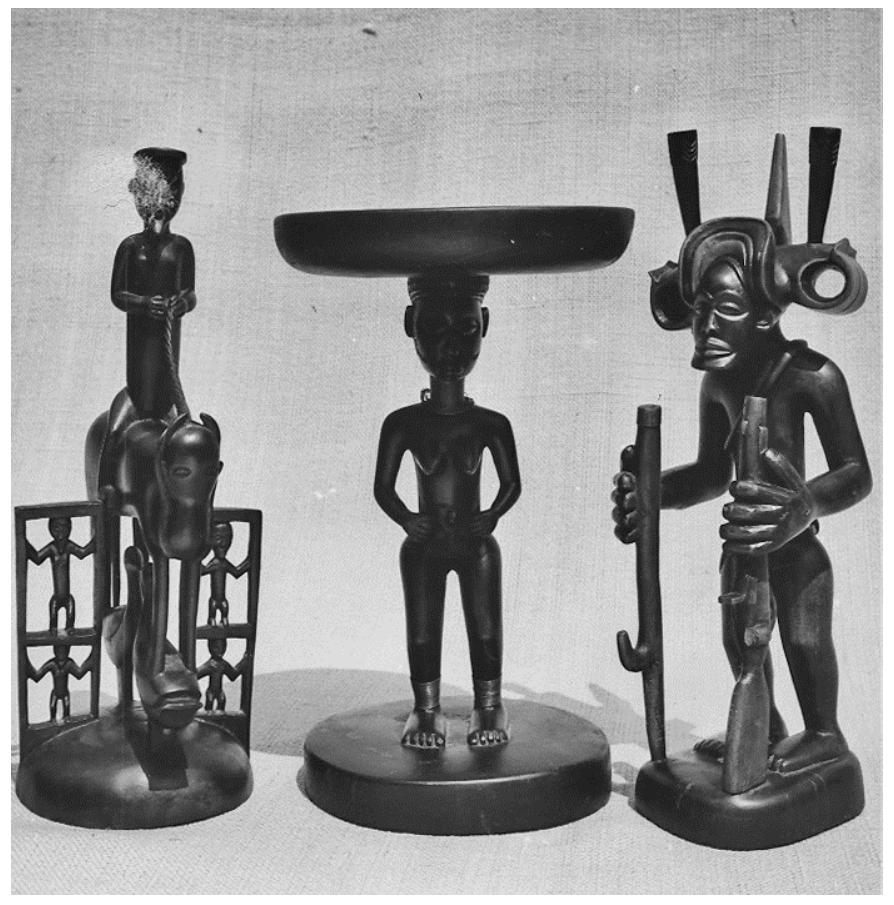

Figura 11 - À direita, peça feita pelo escultor Carinhique baseada na estatueta de Chibinda llunga da "Sala África". Fonte: Diamang (1964). 
39. Diamang (1956, p.19).

40. Vilhena (1963).

41. Diamang (1960, p. 5).

42. Bastin (1999, p. 30).

43. Bastin (1999, p. 30).

A escultura representando Chibinda llunga é a mesma referida no relatório anual do Museu do Dundo de 1956, cuja informação se refere a sua aquisição por Ernesto de Vilhena, que a mantinha em cima de sua mesa de trabalho, antes de decidir enviá-la ao Museu do Dundo. ${ }^{39}$ Até hoje as estatuetas representando esse caçador são extremamente valorizadas e podem ser encontradas no acervo de respeitáveis museus do mundo, como o Museu Etnológico de Berlim e o Museu Nacional de Etnologia de Lisboa.

Se na década de 1950 a orientação era a de que os escultores do Museu do Dundo utilizassem as esculturas adquiridas na Europa como modelo, em 1963, um memorando enviado pelo diretor da Diamang, Júlio de Vilhena, orientava o contrário afirmando: "não vale a pena fazerem cópias de peças antigas já conhecidas e consagradas em publicações e exposições, como por exemplo, a do guerreiro". O motivo não era o simples fato da necessidade de esses artistas explorarem as suas particularidades nas esculturas, mas porque "a que estamos observando, não deixa de mostrar, em relação ao original, decadência por demais evidente". ${ }^{40}$

Uma vez mais, pode-se observar a mudança de orientação no que diz respeito ao trabalho dos escultores do Museu do Dundo. O fato é que ao mesmo tempo que eles eram tidos pelo Museu como os últimos representantes de uma época anterior às mudanças ocasionadas pela situação colonial, a maioria desses homens já havia nascido ou aprendido o ofício quando o colonialismo já estava instaurado em Angola. Em segundo lugar, porque esses escultores não tinham liberdade para criar suas próprias esculturas, ainda que mesmo sob pressão tenham deixado a sua marca individual. No relatório anual de 1960, o próprio Museu reconhece a "mão" de cada artista nas esculturas, referindo-se ao escultor Carinhique que "firmou-se no tipo de rostos (máscaras e cabeças) alongados" enquanto Muachonge "revelou-se com extraordinária habilidade para a cópia de peças de caráter religioso". ${ }^{41}$

Quando esteve realizando pesquisas no Museu do Dundo em 1956, a pesquisadora belga Marie-Lovise Bastin pediu aos escultores Comboia, Cariango e Muanguelengue que reproduzissem uma cariátide feminina de um almofariz de tabaco pertencente ao acervo do Museu. Ao analisar os resultados, Bastin observou que a estatueta produzida por Comboia era a mais fiel à peça do Museu, enquanto Muanguelengue e Cariango fizeram uma interpretação mais livre de suas feições. Muanguelengue deu maior importância para a cabeça da obra e acrescentou ainda na região do ventre uma escarificação típica dos cokwe. Já Cariango, segundo a autora, "apresenta um trabalho imbuído de maior sensualidade, na representação da boca e do peito". ${ }^{42}$

Mesmo que Marie-Louise Bastin tenha deixado claro que, "apesar das diferenças nas proporções e nos pormenores", o resultado evidenciava a maestria técnica dos escultores, a autora ressalta que "essa experiência demonstra que é ainda possível encontrar artesãos de elevada perícia com personalidades fortes, que seriam excelentes artistas se tivessem permanecido ligados a uma tradição verdadeiramente viva". ${ }^{43}$ 
De acordo com as palavras de Bastin, se o tempo em que viviam, por si só, impedia os escultores de serem reconhecidos como excelentes artistas, esses homens nunca poderiam corresponder aos desejos do Museu apenas porque estavam inseridos num contexto diferente dos escultores de antes do colonialismo e, em segundo lugar, porque mesmo os trabalhos dos escultores do chamado "tempo tribal" eram avaliados em termos de autenticidade e originalidade segundo um imaginário construído pelo Ocidente, ligado à ideia de um passado autêntico e um presente inautêntico. ${ }^{44}$ Assim, na prática, os escultores não conseguiriam corresponder aos almejos do Museu, porque eram fictícios.

Igualmente, é relevante considerar que, apesar de esses escultores fazerem parte de um projeto de "amparo e proteção às artes indígenas" e viverem num ambiente evocativo e "protegido" como a Aldeia Museu, na prática, vivenciavam as amarguras da situação colonial. Em 1962, por exemplo, dois escultores foram encaminhados para o posto do Chitato e foram detidos pela Administração colonial. $\bigcirc$ escultor Muachonge, acusado pelo desaparecimento de um boi da Companhia, foi enviado ao posto "para averiguações" e ficou detido entre 7 de março e 25 de maio. Durante o período em que ficou preso, chegou a fazer uma escultura para o administrador do posto. ${ }^{45}$

Nesse mesmo ano o escultor de marfim Mulumba Canhanga deixou claro ao Museu que queria regressar à sua terra natal, o Congo, dizendo: "A Companhia exige muito dos trabalhadores e não paga para isso". Como o Museu não conseguiu fazê-lo mudar de ideia, Canhanga foi encaminhado ao administrador do posto com "o pedido de o convencer a ficar". Preso durante 20 dias, o escultor teria regressado"com outra disposição". Canhanga, enquanto esteve na prisão, também esculpiu um dente de marfim, "propriedade do Administrador do Conselho que the pagou a obra realizada". ${ }^{46}$ No mesmo documento consta ainda que os presos eram obrigados a capinar e efetuar outros trabalhos de interesse da Administração (Figura 12).

Acácio Videira e Mário Fontinha, dois dos principais funcionários portugueses do Museu do Dundo após a saída de José Redinha, em 1958, tentam amenizar a experiência pela qual passou o escultor Mulumba Canhanga. Segundo consta no memorando:

Mulumba Canhanga, após o pagamento do mês de Abril, exaltou-se por the terem descontadas as ausências ao trabalho e, seguidamente, deixou o serviço. Dois dias depois comunicamos a ocorrência à Seção de Informações e Diligências e, viemos a saber mais tarde que esta o enviara à Administração onde ficou detido. Quanto à frase "a Companhia exige muito dos trabalhadores e não paga para isso" - atribuída ao Mulumba (baluba), traduzida por intérprete (quioco) ao empregado europeu da Seção de Informações e Diligências, não nos custa a crer que ela tenha sido aligeirada, pois supomos o Mulumba Canhanga, mais capaz de um desabafo pessoal, do que importar-se com os trabalhadores da Companhia. ${ }^{47}$

A preocupação em perder o escultor de marfim Mulumba Canhanga era muito grande, pois o Museu o considerava como o último de sua categoria.
44. Sobre essa questão, ver Fabian (2013).

45. Memorando (1962).

46. Memorando (1962).

47. Fontinha; Videira (1962). 
Esse documento deixa claro o que acontecia com aqueles que prestavam serviços ou colaboravam com o Museu quando contrariavam os interesses da instituição. Esses homens, que viviam na Aldeia Museu sob a justificativa de que estariam "protegidos" das mudanças que a situação colonial podia provocar em suas produções artísticas, na prática, não estavam nem um pouco imunes à subjugação e violência provocadas por ela, afinal, o Museu e suas ações eram símbolos da prática colonial portuguesa na África.

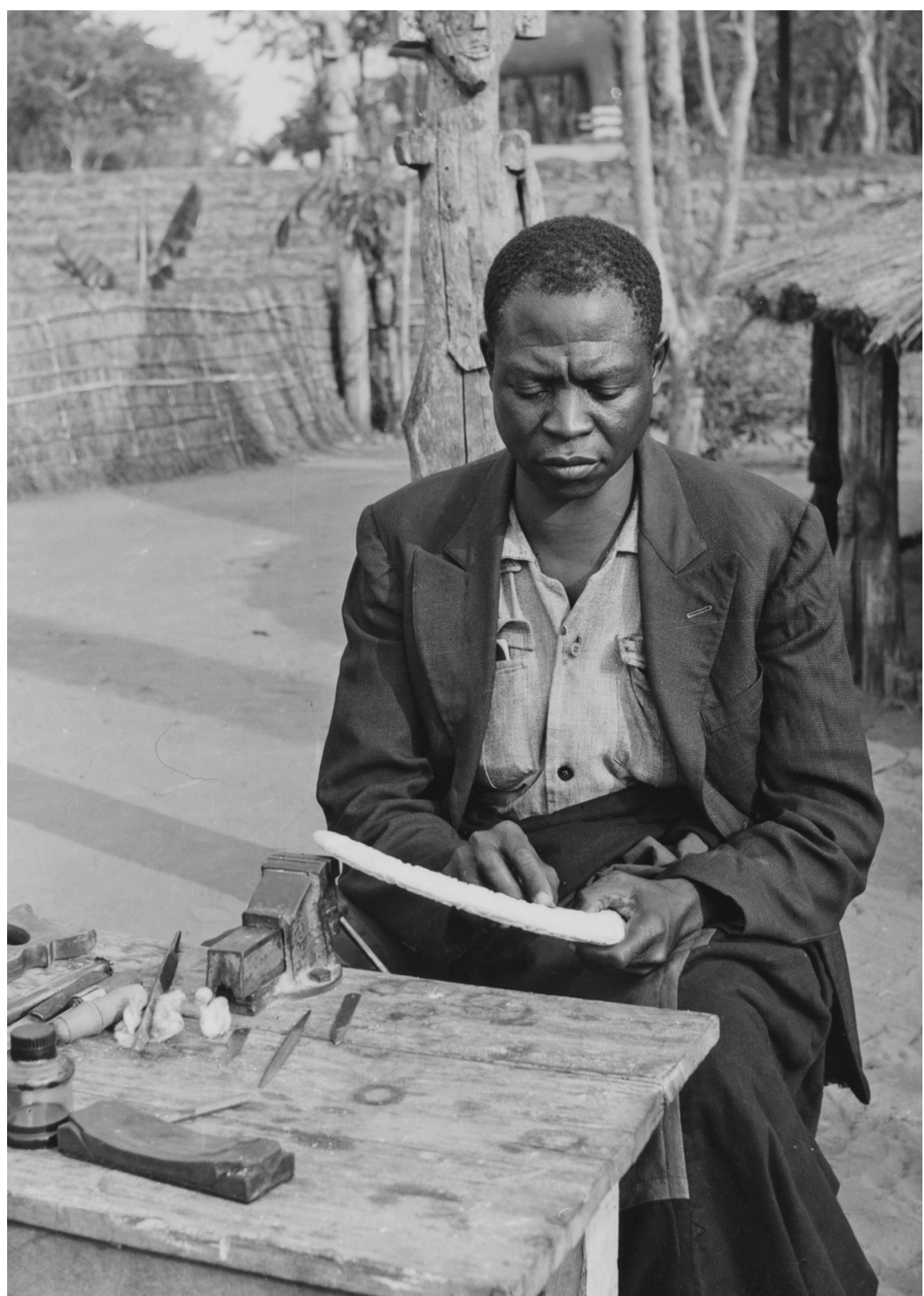

Figura 12 - O escultor de marfim Mulumba Canhanga trabalhando na aldeia do Museu. 1956. Arquivo da Diamang. Acervo do MAUC. 
Não foi apenas a Companhia de Diamantes de Angola, através de seu Museu, que desenvolveu ações de "proteção às artes indígenas". No vizinho Congo belga, em 1935, houve uma exposição de peças "modernas" produzidas por escultores e outros profissionais de toda a colônia sob "os auspícios das autoridades administrativas e comerciais da cidade". Foram exibidos bancos, cadeiras, instrumentos musicais, cestaria, além de trabalhos envolvendo a metalurgia do ferro. ${ }^{48}$

A partir dessa exposição, nesse mesmo ano, o Parlamento belga votou o estabelecimento da Commission pour la Protection des arts et métiers indigènes com objetivos que visavam proteger e estimular a arte indígena, conforme aponta a historiadora da arte Zoe Strother em seu manuscrito "The African Victim in the Congolese Imaginary", em vias de publicação. De acordo com a autora, a comissão declarava que tinha como missão "estudar e pesquisar tudo o que puder contribuir para a proteção, conservação, renovação e progresso das artes e ofícios indígenas". ${ }^{49}$

Além de estimular a formação de ateliês e a venda das produções desses artistas, a Commission entendia como fundamental preservar a arte "do passado". Foi para suprir essa necessidade que o Musée de la Vie Indigène foi criado em Leopodville (atual Kinshasa) no mesmo ano de fundação do Museu do Dundo. Diferente do Museu do Dundo, essa instituição, cujo edifício estava situado num bairro europeu da cidade, estava voltada para um público formado por ocidentais, bem como para os chamados congoleses "évolvés". 50

que ambos os museus compartilhavam era a ideia de que as coleções antigas poderiam servir de inspiração para os novos artistas. No caso específico do Musée de la Vie Indigène havia ainda a ambição de que o Museu fosse um espaço importante para que os administradores que tinham acabado de chegar a Leopoldville pudessem conhecer melhor as culturas das regiões às quais iriam se dirigir. ${ }^{51}$

Valentim Mudimbe em A ideia de África também discute sobre o surgimento dos ateliês no Congo durante o período colonial. Nenhuma das iniciativas se assemelha diretamente ao caso dos escultores do Museu do Dundo, porém converge para a ideia de propor reavivar uma memória estética antiga nos artistas, conceito que, segundo o filósofo congolês,

[...] afigura-se importante enquanto referência a uma configuração perdida e interrompida ou, pelo menos, ofuscada pela história. Sugere uma espécie de inconsciente estético, partilhado pelos africanos subsaarianos, passível de ser despertado por uma procura disciplinada, sensivel e paciente. ${ }^{52}$

Um exemplo citado pelo autor é o do ateliê Le Hangar, localizado em Elisabethville, atual Lubumbashi. Criado após a Segunda Guerra Mundial por Pierre Romain-Desfossés, o ateliê tinha como propósito trabalhar junto aos artistas locais "uma nova estética", no entanto, "reativando" nos seus alunos uma "memória estética, antiga e imutável". Outro caso citado por Mudimbe é o do frade belga Marc Stanislas, que fundou em 1943 a School Saint Luc em Gombe-Matadi,
48. Vanden Bossche (1955, p. 82).

49. Strother (2016).

50. Baeke (no prelo, p. 1, 2).

51. Vanden Bossche (1955, p. 83).

52. Mudimbe (2013, p. 202). 
53. Mudimbe (2013, p. 204). Sobre esse tema, ver também Kasfir; Foster (2013). Especialmente o capítulo "Frank McEwen and Joram Mariga: Patron and artist in the Rhodesian workshop school setting, Zimbabwe", de Elisabeth Morton.

54. Além do importante papel da Forminière na constituição da Diamang, a Companhia de Diamantes de Angola contou também com capitais portugueses (Henry Brunay \& Companhia e do Banco Nacional Ultramarino); capitais belgas (Société Générale de Belgique e da Mutualité Coloniale); capitais franceses (Banque de l'Union Parisienne) e dos Estados Unidos, através do grupo Ryan-Guggenheim. Ao longo da sua existência, outros grupos juntaram-se à Companhia de Diamantes de Angola. Sobre o assunto, ver Porto (2009, p. 5).

55. Diamang (1957c, p.23).

56. Bhabha (1998, p.20). transferida em 1949 para Leopoldville e transformada na Academia de Belas-Artes em 1957. Convicto da teoria de uma "imaginação estética africana inata", durante o seu longo mandato como diretor dessa instituição, o frade obrigou os seus alunos a se inspirarem apenas nas obras ditas "tradicionais", evitando assim a exposição à arte europeia. ${ }^{53}$

Funcionários portugueses do Museu do Dundo tinham conhecimento da existência desses ateliês, pois o número de visitantes belgas que viviam no Congo não era pequeno, e isso se devia ao fato de que o Dundo ficava próximo da fronteira, além da relação próxima da Diamang com a Forminiére, empresa que, inclusive, deu origem à Companhia de Diamantes de Angola. ${ }^{54}$

Em abril de 1957 o Museu do Dundo recebeu a visita do sr. Armand Vanhee, encarregado de Missão Especial do Ministério das Colônias da Bélgica, e do sr. Désiré Petry, inspetor de Ensino da Província de Kasai. Foi através desses visitantes que o Museu do Dundo soube de mais detalhes dos "ateliês sociais de arte indígena, que parecem estar a atingir no Congo plena voga". Não é demais reiterar que esses ateliês tinham como missão a "manutenção da arte indígena e, ao mesmo tempo, conduzir os nativos de modo a traduzirem, segundo os processos, técnicas e materiais de 'ateliê' europeu, as suas tendências e inspirações artísticas". ${ }^{55}$

3 Algumas considerações finais

A relação entre os escultores e o Museu do Dundo parece ter sido marcada por insatisfações de ambos os lados. Do lado dos escultores havia a própria situação colonial que os desfavorecia em todos os aspectos. Mas apesar de vivenciarem os dramas do colonialismo, artisticamente esses escultores eram pressionados a produzirem como no "tempo tribal", um tempo imaginado e construído pelos próprios colonizadores como aquele das produções artísticas originais e autênticas, livres de qualquer influência externa. Assim, compreende-se a permanente insatisfação do Museu do Dundo em relação a esses homens que dificilmente poderiam satisfazer os almejos do Museu.

Os escultores privativos do Museu do Dundo que parecem ser sujeitos "sem lugar", antes, são sujeitos do "entre-lugar", segundo o conceito proposto por Homi Bhabha. Afinal, de acordo com esse autor, "esses 'entre-lugares' fornecem o terreno para a elaboração de estratégias de subjetivação - singular ou coletiva que dão início a novos signos de identidade e postos de colaboração e contestação, no ato de definir a própria ideia de sociedade". 56 


\title{
REFERÊNCIAS
}

\author{
FONTES IMPRESSAS
}

COMPANHIA DE DIAMANTES DE ANGOLA (DIAMANG). Museu do Dundo: relatório anual, 1936. Dundo (Angola), 1936.

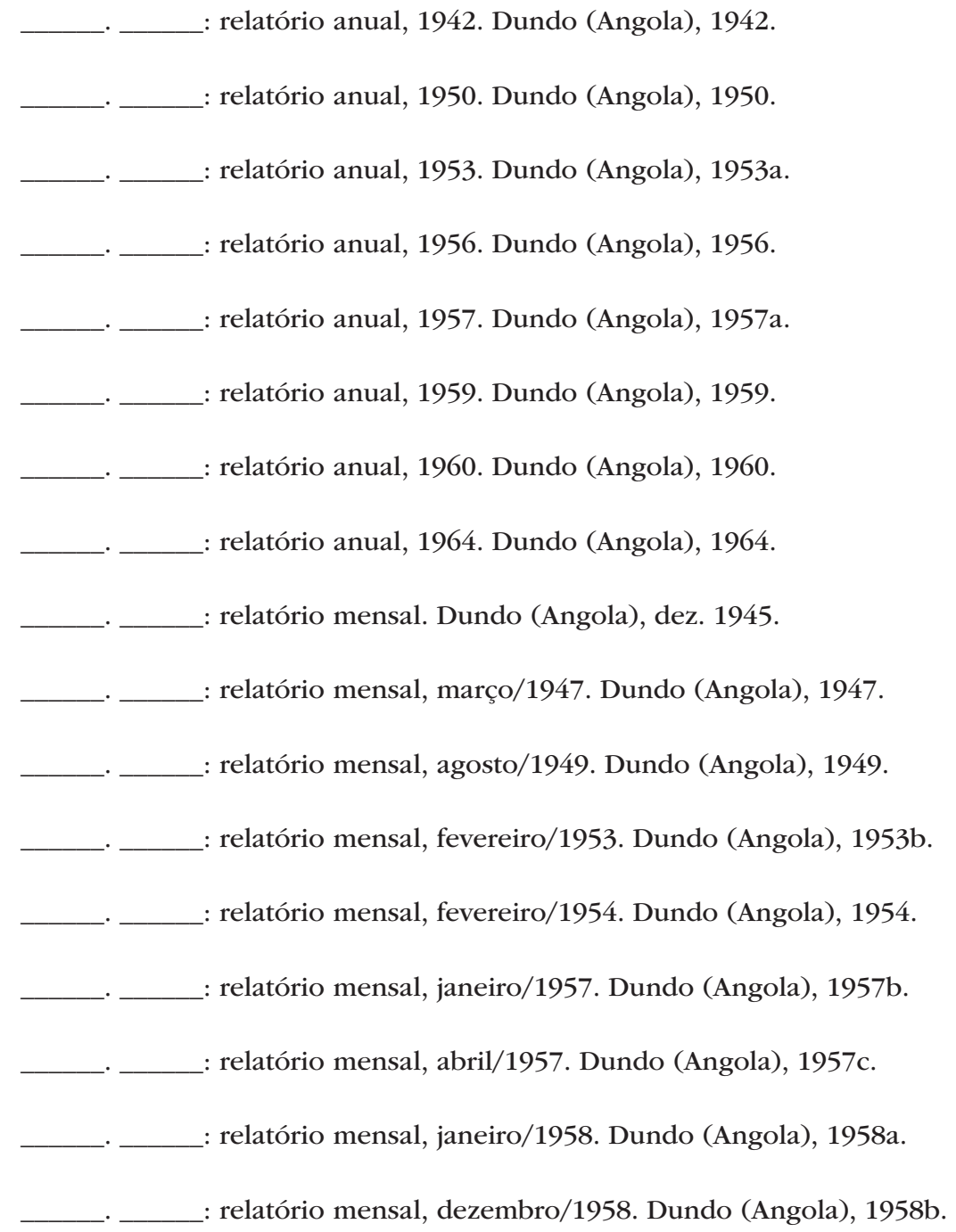


FONTINHA, Mário; VIDEIRA, Acácio. [Memorando n. 58] 18 ago. 1962, Museu do Dundo [para] Seção de Informações e Diligências.

; __ [Memorando n. 110] 25 mar. 1966, Museu do Dundo [para] sede da Dia-

mang. Lisboa.

MEMORANDO n. 58. Dundo, 1 ago. 1962, Seção de Informações e Diligências [para] Museu do Dundo. (Assinado pelo chefe da Seção de Informações e Diligências).

VILHENA, Júlio de. [Memorando $n$. 57] 25 jan. 1963, Lisboa [para] Museu do Dundo.

LIVROS, ARTIGOS E TESES

AMARAL, Ana Rita; MARTINS, Maria do Rosário. Os escultores do Museu do Dundo e o imaginário da Arte Cokwe: estudo de uma coleção. Boletim da Sociedade de Geografia de Lisboa, Lisboa, série 128 ${ }^{\text {, }}$, n. 1-12, p. 157-174, jan.-dez. 2010.

BAEKE, Viviane. L'exposition permanente de l'IMNC: Métamorphoses de l'approche muséale des arts congolais à Kinshasa. No prelo.

BASTIN, Marie-Louise. Arte Decorativa Cokwe. Lisboa: Museu Antropológico da Universidade de Coimbra; Museu do Dundo, 2009. 2 v.

Escultura Tshokwe. Porto: Edição CEAUP \&DCTP, 1999.

BHABHA, Homi. O local da cultura. Belo Horizonte: Ed. UFMG, 1998.

BEVILACQUA, Juliana Ribeiro da Silva. De caçadores a caça: sobas, Diamang e o Museu do Dundo. São Paulo, 2016. Tese (Doutorado em História Social) - Faculdade de Filosofia, Letras e Ciências Humanas, Universidade de São Paulo. Disponível em: <http://www.teses. usp.br/teses/disponiveis/8/8138/tde-25082016-132727>.Acesso em: 6 jun. 2017.

CORNET, Joseph. African art and authenticity. African Arts, Cambridge (USA): MIT Press, v. 9, n. 1, p. 52-55, Autumm 1975.

ERRINGTON, Shelly. The Death of Authentic Primitive Art and Other Tales of Progress. Berkeley; Los Angeles: University of California Press, 1998.

FABIAN, Johannes. O Tempo e o outro. Petrópolis: Vozes, 2013.

HEUSCH, Luc de. La vipère et la cigogne. In: FALGAYRETTES, Christiane (Org.). Arte e Mythologie: Figures tchokwe. Paris: Editions Dapper, 1988. 
JORDÁN, Manuel. Os Tshokwe e povos aparentados. In: HERREMAN, Frank. (Org.). Na presença dos espíritos. Nova York: Museum for African Art, 2000.

KASFIR, Sidney Littlefield. African Art and Authenticity: A text with a shadow. In: OGUIBE, Olu; ENWEZOR, Okwui. (Ed.). Reading the Contemporary African art from theory to the Marketplace.Trad. Marina Santos. Cambridge (USA): The MIT Press, 1999. p.94.

; FOSTER, Till. (Eds). African art and agency in the workshop. Bloomington: Indiana

University Press, 2013.

MUDIMBE, Valentin Yves. A ideia de África. Luanda: Edições Mulemba; Lisboa: Edições Pedago, 2013.

PORTO, Nuno. Modos de objectificação da dominação colonial: o caso do Museu do Dundo, 1940-1970. Lisboa: Fundação Calouste Gulbenkian; Fundação para a Ciência e a Tecnologia, 2009.

PRICE, Sally. Arte primitiva em centros civilizados. Rio de Janeiro: Editora UFRJ, 2000.

REDINHA, José. Distribuição étnica de Angola. 5. ed. Luanda: Centro de Informação e Turismo de Angola, 1971.

STEINER, Christopher. African Art in transit. New York: Cambridge University Press, 1994.

STROTHER, Zoe Sarah. The African Victim in the Congolese Imaginary. In: Humor and Violence: Seeing Europeans in Central African Art. Bloomington (USA): Indiana University Press, 2016.

THOMAZ, Omar Ribeiro. O bom povo português: usos e costumes d'aquém e d'além-mar. Mana, Rio de Janeiro: UFRJ, v.7, n. 1, p. 55-87, abr. 2001.

VANDEN BOSSCHE, Jean. Le Musée de la Vie Indigène, Léopoldville, Congo Belge. Museum International, v. 8, n. 2, p. 82-88, 1955.

VANSINA, Jan. Ndop: Royal statues among the Kuba. In: FRASER, Douglas; COLE, Herbert (Ed.) African art and Leadership.Madison (USA): University of Wisconsin Press, 1972.

Artigo apresentado em 16/10/2016. Aprovado em 26/04/2017 